\title{
CORRESPONDENCE
}

We welcome letters to the Editor concerning articles which have recently been published. Such letters will be subject to the usual stages of selection and editing; where appropriate the authors of the original article will be offered the opportunity to reply.

Letters should normally be under 500 words in length, double-spaced throughout, signed by all authors and fully referenced. The edited version will be returned for approval before publication.

\section{VARUS DEROTATIONAL OSTEOTOMY FOR PERSISTENT DYSPLASIA IN CDH}

Sir,

We wish to comment on the article in the September 1995 issue by Suda et al entitled 'Varus derotational osteotomy for persistent dysplasia in congenital dislocation of the hip' (1995;77-B:75661 ). We would like to know the preoperative degree of dislocation which will tell us the amount of shortening necessary to reduce the head concentrically. In high dislocated hips we have generally seen residual shortening in the longer follow-up period (Chakirgil 1987).

Did the authors encounter problems with avascular necrosis or were such patients excluded from the study? We have seen this complication in patients younger than those of the authors and this complication has a profound effect on the outcome (Mergen et al 1991a; Binnet et al 1992), and influences the remodelling of the proximal femur.

In the older child, concentric reduction is likely to be difficult, and increases the risk of maldevelopment of the hip. We have found that the age of the child at operation has considerable influence on the outcome in both soft-tissue and bony procedures (Chakirgil 1987; Mergen et al 1991a,b; Binnet et al 1992; Ömerõglu and Ateçs, unpublished). Suda et al have compared two groups of patients with a difference in average age; three years for the varus derotation osteotomy group and six years for the group in which this was combined with a Salter procedure.

Finally, Table III quotes five cases of Severin class-IV patients while Table IV indicates six cases.

\section{Y. ATEÇS, MD}

H. ÖMERÕGLU, MD

Ankara Hospital

Ankara, Turkey.

Binnet MS, Chakirgil GS, Adiyaman S, Ateçs Y. The relationship between the treatment of congenital dislocation of the hip and avascular necrosis. Orthopaedics 1992;15:73-81.

Chakirgil GS. Radical reduction operation in the treatment of congenital dislocation of the hip: an analysis of 2789 cases. Orthopedics $1987 ; 10: 711-20$

(C)1996 British Editorial Society of Bone and Joint Surgery

0301-620X/96/57028 \$2.00

J Bone Joint Surg [Br] 1996;78-B:853-6.
Mergen E, Adyaman S, Ömerõglu H, Erdemli B, Içsiklar U. Medial approach open reduction for congenital dislocation of the hip using the Ferguson procedure: a review of 31 hips. Arch Orthop Trauma Surg 1991a;110:169-72

Mergen E, Içsiklar ZU, Ömerõglu H, Ateçs Y, Erdemli B. Combination of open reduction, Salter and femoral osteotomies in the treatment of congenital dislocation of the hip. J Fac Med Univ Ankara, 1991b; 44:563-74.

Suda H, Hattori T, Iwata H. Varus derotation osteotomy for persistent dysplasia in congenital dislocation of the hip: proximal femoral growth and alignment changes in the leg. J Bone Joint Surg $[\mathrm{Br}]$ 1995; 77-B:756-61.

Author's reply:

Sir

I would like to respond to the questions raised by Dr Ateçs and Dr Ömerõglu. First, with regard to the preoperative degree of dislocation, in the femoral osteotomy group the $\mathrm{CE}$ angle was $-22^{\circ}$ to $+17^{\circ}$ and the acetabular angle $30^{\circ}$ to $52^{\circ}$. In the femoral osteotomy and Salter group the CE angle was $-32^{\circ}$ to $+8^{\circ}$ and the acetabular angle $25^{\circ}$ to $47^{\circ}$. The indication for surgery was the attainment of joint congruity by osteotomy. We have not studied hips with high dislocation in detail.

The influence of avascular necrosis on the morphology of the neck is considerable. Our patients who had avascular necrosis usually showed varus of the neck and shortening and deformity of the head. We excluded these from our series since we were principally interested in the influence of osteotomy on the development of the neck, as was equally true regarding the age of the patients. We agree with their views on the influence of age on the results.

We apologise for the inconsistency in Tables III and IV. Table IV is correct.

H. SUDA, MD

Tokai Municipal Hospital

Aichi, Japan.

\section{PATELLAR RESURFACING VERSUS RETENTION IN TOTAL KNEE ARTHROPLASTY}

Sir,

In their paper in the March 1996 issue entitled 'Patellar resurfacing versus retention in total knee arthroplasty' (1996;78-B:226-8)

Feller et al make a solid case for not resurfacing the patella based on good clinical results when using this approach. Considering the biomechanical linkages between the patella and the posterior cruciate ligament, it is important for the authors to describe their operative treatment of this ligament.

R. P. GRELSAMER, MD

927 49th Street

New York, USA

Feller JA, Bartlett RJ, Lang DM. Patellar resurfacing versus retention in total knee arthroplasty. J Bone Joint Surg [Br] 1996;78-B:226-8. 
Author's reply:

Sir,

I thank Dr Grelsamer for his comment. The posterior cruciate ligament was retained in each case in keeping with the surgical technique recommended by the manufacturers of the PCA Modular prosthesis (Howmedica, Rutherford, New Jersey).

I agree that the issue of the posterior cruciate ligament is important with regard to the loading of the patella. By retaining the posterior cruciate ligament, we believe that changes in loading were kept to a minimum.

J. FELLER, FRACS

Austin Hospital

Melbourne, Australia.

\section{ARTICULAR DEBRIDEMENT VERSUS WASHOUT FOR DEGENERATION OF THE MEDIAL FEMORAL CONDYLE}

Sir,

I read with interest the paper by Mr Hubbard in the March 1996 issue entitled 'Articular debridement versus washout for degeneration of the medial femoral condyle' (1996;78-B:217-9) and was impressed with the result. I must point out, however, some inaccuracies in the discussion.

The paper by Dawes, Kirlew and Haslock (1987) compared lavage of the joint through a 14-gauge needle with aspiration and injection of saline, showing no difference in either group of patients at three months. The paper by myself and my colleagues (Livesley et al 1991) considered arthroscopy of the joint and lavage as against physiotherapy. We were able to exclude other pathology and this was one of the criteria of entry to the study. A grading of the arthritis was provided using the Thomas system and we were able to demonstrate an improvement with lavage as compared with physiotherapy. We agree, however, with the conclusions of $\mathrm{Mr}$ Hubbard that the procedure is best used for femorotibial osteoarthritis, particularly of the medial compartment, and is of little benefit for patellofemoral osteoarthritis. Mechanical malalignment and joint laxity did not correlate well with a good result.

P. J. LIVESLEY, MCh Orth, FRCS Orth

The Park Hospital

Arnold, UK.

Dawes PT, Kirlew C, Haslock I. Saline washout for knee osteoarthritis: results of a controlled study. Clin Rheumatol 1987;6:61-3.

Hubbard MJS. Articular debridement versus washout for degeneration of the medial femoral condyle: a five-year study. J Bone Joint Surg [Br] 1996;78-B:217-9.

Livesley PJ, Doherty M, Needoff M, Moulton A. Arthroscopic lavage of osteoarthritic knees. J Bone Joint Surg [Br] 1991;73-B:922-6.

\section{Author's reply:}

Sir

I am very grateful to Mr Livesley for his kind appreciation of my paper and for rightly pointing out that washout versus physiotherapy was the subject of his trial and not that of Dawes et al.

M. J. S. HUBBARD, MChir, FRCS

Glan Clwyd District General Hospital

Rhyl, UK.
Sir,

In his paper in the March 1996 issue entitled 'Articular debridement versus washout for degeneration of the medial femoral condyle' (1996;78-B:217-9) Mr Hubbard is to be applauded for asking whether arthroscopic variations of the Pridie procedure are of value. His study, however, misses the point. We all accept (or should) that joints remain normal for a very short time after complete maturation (Bennett, Waine and Bauer 1942). The question therefore is whether the wear observed is mechanically and symptomatically significant. The correct approach is not to extract cards from envelopes, but to exercise clinical judgement at operation.

Loose meniscal or articular flaps and loose bodies require removal, but in their absence I am not clear what debridement may achieve.

J. NOBLE, FRCS, FRCS Ed

BUPA Hospital

Manchester, UK.

Bennett GA, Waine J, Bauer W. Changes in the knee joint at various ages. New York: The Commonwealth Fund, 1942.

Hubbard MJS. Articular debridement versus washout for degeneration of the medial femoral condyle: a five-year study. J Bone Joint Surg [Br] 1996;78-B:217-9.

\section{Author's reply:}

Sir,

I am grateful to Mr Noble for his letter and his interest. All the lesions observed in both parts of this trial were unstable, and on probing showed signs of shedding a piece of articular cartilage. I wished to determine whether in this situation articular debridement was better than simply washing out the joint, and showed that debridement was more efficacious than washout. When 'clinical judgement' rather than randomisation is used in a trial, the results can no longer be comparable.

M. J. S. HUBBARD, MChir, FRCS

Glan Clwyd District General Hospital

Rhyl, UK..

\section{TRANSCARDIAC ECHOCARDIOGRAPHY DURING INVASIVE INTRAMEDULLARY PROCEDURES}

Sir,

We read with interest the article in the May 1995 issue by Christie et al entitled 'Transcardiac echocardiography during invasive intramedullary procedures' (1995;77-B:450-5). The authors point out that although clinically apparent pulmonary embolism is a rare occurrence after intramedullary procedures, transcardiac echocardiography reveals embolic showers in more than $90 \%$ of the patients and lasts for a mean of $7 \mathrm{~min}$ and $2.5 \mathrm{~min}$, respectively, in cemented and uncemented arthroplasties. During the insertion of cement Svartling (1988) reported a mean duration of 20 to $83 \mathrm{~s}$ with a maximum of 3 min depending on the procedure adopted.

We have used spectral analysis of the Doppler signal recorded for five minutes on the femoral vein on the side of operation in 28 consecutive patients, precisely two hours after total hip $(n=15)$ and knee $(n=13)$ replacement. High-intensity transient signals were found in 9 and 11 subjects after hip and knee arthroplasty, respectively. Although the size of particles could not be deter- 
mined, the average number recorded per minute ranged from 0.8 to 168 , indicating that embolic showers after arthroplasty are more prolonged than have been previously reported.

Transcardiac echocardiography allows for the measurement of the size of particles, but severe complications may sometimes occur after this procedure. Recording of the Doppler signal from a peripheral vein is an easy technique and can be performed after the operation. Spectral analysis of the Doppler signal has proved to be accurate and reproducible in the detection of circulating particles (Stump et al 1991) and is now frequently used in clinical practice (Tegeler 1994).

Further studies are needed to define the mean duration of the microembolic phenomenon and its consequences on the pulmonary vascular bed.

P. ABRAHAM, MD

J. R. MILLOT, MD

L. PIDHORZ, MD

J. L. SAUMET, MD

Centre Hospitalier Universitaire

49033 Angers Cedex 01

France.

Christie J, Robinson CM, Pell ACH, McBirnie J, Burnett R. Transcardiac echocardiography during invasive intramedullary procedures. J Bone Joint Surg [Br] 1995;77-B:450-5.

Stump DA, Stein CS, Tegeler CH, et al. Validity and reliability of an ultrasound device for detecting carotid emboli. J Neuroimag 1991; 1:18-22.

Svartling N. Detection of embolized material in the right atrium during cementation in hip arthroplasty. Acta Anesthesiol Scand 1988;32: 203-8.

Tegeler CH. High intensity transient signals detected by Doppler ultrasonography: searching for answers. Cerebrovasc Dis 1994;4:379-82.

\section{Author's reply:}

Sir,

I was very interested to read the letter by Abraham et al reporting high-intensity transient signals during Doppler investigations of the ipsilateral femoral vein two hours after total hip and knee replacement. We used transoesophageal echocardiography during invasive intramedullary procedures with a $5 \mathrm{MHz}$ biplane echo probe. While this technique allowed peroperative observation of embolic sequences in the right atrium we were unable to observe cardiac circulation in the postoperative period as the echo probe was removed before reversal of anaesthesia.

About $90 \%$ of patients undergoing intramedullary reaming or cementing have transatrial echogenic emboli during the procedure, but these usually cease when it stops.

Squeezing of the calf or thigh, however, can produce further emboli. In a small number of patients (1\% to $2 \%$ ) emboli can still be recorded after the intramedullary procedure has ceased and may be seen until the echo probe is removed from the oesophagus.

The detection of emboli two hours after total hip and knee replacement is interesting. It is possible that residual fat and marrow particles continue to embolise long after the operation has ended, but our research suggests that extrusion from the marrow cavity stops fairly soon after reaming. We have noticed activation of the coagulation system associated with intramedullary procedures and there may be a local coagulative process in the venous circulation of the leg which leads to continuing embolic showers. We do not yet know for how long this activation of coagulation continues.

Abraham et al have reported an interesting finding that requires further investigation and we look forward to hearing more of their work in the future.

J. CHRISTIE, FRCS Ed

Royal Infirmary of Edinburgh

Edinburgh, UK.

\section{OBESITY AND QUALITY OF LIFE AFTER PRIMARY HIP ARTHROPLASTY}

Sir,

I read with interest the article in the January 1996 issue entitled 'Obesity and quality of life after primary hip arthroplasty' by Chan and Villar (1996;78-B:78-81). The findings suggest that there is no difference in the quality of life three years after total hip arthroplasty in non-obese, mildly obese and moderately obese patients.

There is no indication, however, as to the type of prosthesis used or whether cemented or uncemented components were inserted. Did all the patients in all the groups have the same procedure? Also, no indication is given as to whether there was an increase in morbidity either peri- or postoperatively. Ten patients died before one year. Although the authors state that "these patients did not differ significantly from the remaining patients" we are not told how they died and to which groups they belonged. Obese patients are generally thought to have an increase in postoperative complications some of which could significantly reduce the quality of life.

The authors do not address the problem of implant failure which would lead to an increase in morbidity. There were only 25 patients in the grade-II obese group. With an expected rate of failure of 5\% (Marston, Cobb and Bentley 1996) it is unlikely that a statistically significant difference could be demonstrated, and the short follow-up of three years is, in any case, too early to assess this. Dickob and Martini (1996) found that four to seven years after uncemented total hip arthroplasty, obese patients (body mass index > 1.3) had a two-fold increase in the incidence of loosening.

Chan and Villar suggest that while weight reduction is recommended before total hip arthroplasty, patients should not be denied surgery on the basis of obesity alone. If these patients require earlier or multiple revisions then a marked reduction in quality of life will ensue at a later stage.

This study is incomplete and on the basis of the current findings it cannot be recommended that obese patients are offered hip arthroplasty on the same basis as the non-obese.

P. C. NOLAN, MD, FRCS

Musgrave Park Hospital

Belfast, UK.

Chan CLH, Villar RN. Obesity and quality of life after primary hip arthroplasty. J Bone Joint Surg [Br] 1996;78-B:78-81.

Dickob M, Martini T. The cementless PM hip arthroplasty: four-toseven-year results. J Bone Joint Surg [Br] 1996;78-B:195-9.

Marston RA, Cobb AG, Bentley G. Stanmore compared with Charnley total hip replacement. J Bone Joint Surg [Br] 1996;78-B:178-84.

\section{Author's reply:}

Sir,

Thank you for giving us the opportunity to reply to the letter from Mr Nolan. We are slightly concerned that he has entirely missed the point of the paper. We did not aim to examine all aspects of 
hip replacement in the obese patient, but to look specifically at the improvement in quality of life. As orthopaedic surgeons, we tend to focus on the postoperative complications, the mortality associated with surgery and the longevity of the prostheses, and these concerns may be used as an excuse for denying the obese patient a hip replacement.

In spite of such considerations an obese patient will demonstrate as significant an improvement in quality of life after surgery as a non-obese person. In the study we looked at both Charnley and hybrid total hip replacements. The ten patients who died before one year were scattered equally throughout the various groups, and the improvement in the quality of life was identical in each. We accept that it is possible that the obese patients will demonstrate earlier failure of the implant than the non-obese, but, currently, we are not aware of any evidence which will allow us to predict the future for our group.

Even if the obese patients do show earlier failure of the implant, should they really be denied an operation that can be demonstrated to improve the quality of life so much?

\section{R. N. VILLAR, MS, FRCS \\ Cambridge Lea Hospital \\ Cambridge, UK}

\section{QUESTIONNAIRE ON THE PERCEPTIONS OF PATIENTS ABOUT TOTAL HIP REPLACEMENT}

\section{Sir,}

May I comment on the paper in the March 1996 issue by Dawson et al entitled 'Questionnaire on the perceptions of patients about total hip replacement' (1996;78-B:185-90).

Any method which gives an accurate assessment of outcome must be considered to be a valuable contribution. The questionnaire which the authors present is certainly short and practical but is it really sensitive? Clinical experience dictates that patients, and even doctors, are not always accurate in making the diagnosis of what is considered to be 'hip pain'; it may not necessarily arise from the hip. At what stage and by whom was the diagnosis made and what evidence confirmed the patients' perceptions? Since, after total hip replacement, the natural joint is no longer present can any interpretation of symptoms be labelled as 'hip pain' and does a failed total hip replacement present as 'hip pain'?

B. M. WROBLEWSKI, FRCS

Wrightington Hospital for Joint Disease

Wigan, UK.

Dawson J, Fitzpatrick R, Carr A, Murray D. Questionnaire on the perception of patients about total hip replacement. J Bone Joint Surg [Br] 1996;78-B:185-90.

\section{Author's reply:}

Sir,

Professor Wroblewski raises a number of important issues about the use of patient-based questionnaires such as that which we have devised. These are not intended for diagnosis but for use in patients who have already been fully assessed by the surgeon to determine diagnosis and the appropriateness of surgery.

Our questionnaire is intended to be a method of assessing outcome in patients who have undergone operation. Professor Wroblewski is correct in saying that patients may still make incorrect attributions regarding pain in follow-up studies, but our questionnaire appears less prone to misleading results than other more general assessments such as the Arthritis Impact Measurement Scales and the SF-36 in which patients report pain, dysfunction and problems of mobility. Our experience and that of others examining health-status measures for use in orthopaedic surgery (Bombardier et al 1995), suggest that broader measures are likely to detect problems of pain which, although important to the patient, are not related to the investigation.

Our approach is not perfect, simply less imperfect than others. Use of our questionnaire in more long-term follow-up studies is now needed to test its value.

\section{R. FITZPATRICK, $\mathrm{PhD}$ \\ University of Oxford \\ Oxford, UK.}

Bombardier C, Melfi CA, Paul J, et al. Comparison of a generic and a disease-specific measure of pain and physical function after knee replacement surgery. Med Care 1995;33 Suppl 4 AS131-44. 